Egyptian Journal of Aquatic Biology \& Fisheries

Zoology Department, Faculty of Science,

Ain Shams University, Cairo, Egypt.

ISSN $1110-6131$

Vol. 22(5): 273- 284 (2018)

www.ejabf.journals.ekb.eg

\title{
Effect of technological processing on the safety of Indian mackerel (Rastrelliger kangurata) from Suez, Egypt
}

\author{
Hesham F. Amin ${ }^{1}$, Omaima M. Ahmed ${ }^{1}$, Abdel-hamied M. Rasmey ${ }^{2}$, \\ Alaa M. Younis ${ }^{3}$, Alaa El-Din A. Bekhit ${ }^{4}$
}

1- Department of Fish Processing and Technology, Faculty of Fish Resources, Suez University, Suez, Egypt.

2- Department of Botany and Microbiology, Faculty of Science, Suez University, Egypt.

3- Department of Aquatic Environment, Faculty of Fish Resources, Suez University, Egypt.

4- Department of Food Science, University of Otago, Dunedin, New Zealand.

*Corresponding author: alaa.younis@suezuniv.edu.eg, ala_den@yahoo.com

\author{
ARTICLE INFO \\ Article History: \\ Received: Nov.3, 2018 \\ Accepted:Dec. 7, 2018 \\ Available online: Dec., 2018
}

Keywords:
Indian mackerel
Rastrelliger kangurata
Suez
Processing
Safety
heavy metals
canning
Salmonella

\begin{abstract}
This study investigated the effect of different fish processing technologies on the bacteriological safety and heavy metal contents of Indian mackerel fish products. Mackerel was processed by salting (dry salt $15 \%$ ), hot marinating $(2.5 \%$ acetic acid and $3 \% \mathrm{NaCl})$ or canning (hot vegetable oil, brine $3 \%$ or tomato sauce $8 \%$ ). Fresh, chilled fish from the local market had an aerobic colony count of $5.1 \pm 0.2 \mathrm{logs} \mathrm{CFU} / \mathrm{g}$ and the presence of Salmonella enterica was confirmed using API diagnostics and 16S rDNA. Marination and salting resulted in 4 and $1.3 \operatorname{logs} \mathrm{CFU} / \mathrm{g}$ reduction in aerobic colony counts, respectively. Canning eliminated all viable bacterial growth, regardless of filling medium (vegetable oil, brine or tomato sauce). Processing technologies had no effect on the heavy metal $(\mathrm{Hg}, \mathrm{Cd}, \mathrm{Pb}$, and $\mathrm{Cu}$ ) content of the fish products. The estimated daily and weekly intake values of $\mathrm{Pb}$ and $\mathrm{Cd}$ from fresh fish and their products were below the recommended safety regulations. Canning, followed by marination, were the safer options for the preservation of Indian mackerel (compared to salting).
\end{abstract}

\section{INTRODUCTION}

Fish has a high nutritional value and is considered a perishable food when its quality deteriorate during storage and/or during processing. Many consumers change their acceptance and preference towards fish products over time. Pathogenic bacteria such as Listeria monocytogenes, Salmonella enterica and Vibrio parahaemolyticus are commonly associated with fish products (Song et al., 2011) and the risk associated with these pathogens needs to be established for general public health. Thus, aerobic colonies and pathogenic bacteria of public health importance are used to examine the quality of fish and its products (Mol and Tosun, 2011). 
The preservation of fish and the processing options used during fish processing have a great impact on the safety and sensory attributes of the final product. Manufacturing procedures such as control of salt content, $\mathrm{pH}$ and heat are very important to ensure the safety of the final fish product (Oxen and Knorr, 1993; Van Opstal et al., 2003; Molina-Höppner et al., 2004; Sevenich et al.,2013). However, cured fish products containing different amounts of preservatives (salt or vinegar) and thermally-processed products have different safety levels.

Increasing human activities near coastal areas have caused more attention regarding risks to seafood contamination and thus human health resulting from environmental pollution (Shreadah et al., 2006; Said et al. 2006; Younis \& Nafea 2012; El Zokm et al., 2015; Younis, 2018a; Younis, 2018b).

Heavy metal elements such as mercury $(\mathrm{Hg})$, lead $(\mathrm{Pb})$ and cadmium $(\mathrm{Cd})$ are the most common contaminant heavy metals in the aquatic environment and their accumulation in fish leads to potential health risks upon consumption (Kalay et al., 1999; Emami et al., 2005; Younis et al., 2014; Soliman et al., 2018). Continuous evaluations and safety guidelines have been provided by the Food and Agriculture Organisation of the United Nations (FAO) and World Health Organisation (WHO) (FAO/WHO, 2004) to support efforts to control this risk.

Total Egyptian fish landings from the Red Sea and Gulf of Suez have increased from 14,700 tons in 1980 to around 45,053 tons in 2014 (FAO, 2004; FSYB, 2014). The Indian mackerel fish (Rastrelliger kanagurta) is a pelagic species regarded as an important source of inexpensive protein and comprises about $22 \%$ of all catch from Egyptian waters. Due to the importance and widespread availability of salted, marinated and canned fish products in Egypt as well as many other African, Asian and European countries, the present investigation aimed to study the effect of these processing technologies on the heavy metal content and bacteriological safety of salted, marinated and canned Indian mackerel products.

\section{MATERIALS AND METHODS}

\section{Materials}

Fresh marine Indian mackerel (Rastrelliger kangurata), known locally as Cascomry, with an average length of $23 \pm 3.0 \mathrm{~cm}$ and weight of $135 \pm 19.7 \mathrm{~g}$ were used in this study. The fish were purchased from ten different local fish markets $(2 \mathrm{~kg}$ fish from each store) in Suez, Egypt in March 2016. A total of $20 \mathrm{~kg}$ of fish were transferred to the laboratory in polystyrene boxes filled with crushed ice. Ice was prepared in the lab using sterilised distilled water and was hygienically prepared and handled.

Other materials included refined coarse salt, obtained from the El-Nasr Salines Company, natural sugarcane vinegar (5\%) from the Agrocorp Company (Suez, Egypt), tomato sauce (22\%) from Heinz Egypt, edible blend oil (sunflower oil and soybean oil) from the Food Industry Holding Company (FIHC) and glass jars (capacity 250g) with screw metal lids and polyethylene bags were obtained from the Suez commercial market (Egypt).

\section{Technological processes}

The fresh Cascomry were washed and divided into four groups. One group was used fresh and the other three were assigned to one of three treatments: dry salted, hot marinated or canned products, as follows:

\section{Salting process}


Fish were placed in layers interposed with layers of salt $(15 \%)$ in tight polyethylene plastic containers. The packs were stored at room temperature for two weeks until ripening.

\section{Hot marinating process}

Fish were filleted, quickly washed under running water and soaked in $10 \%$ brine solution for $10 \mathrm{~min}$. The salted fillets were steamed under atmospheric pressure for $15 \mathrm{~min}$, cooled at room temperature $\left(23^{\circ} \mathrm{C} \pm 2{ }^{\circ} \mathrm{C}\right)$, packed in glass jars and covered at $1: 1(\mathrm{w} / \mathrm{v})$ ratio with marinating solution $(2.5 \%$ acetic acid and $3 \%$ sodium chloride, $\mathrm{NaCl}$ ). The final product was prepared to be a fast-processed product, stored in a refrigerator at a temperature of $4 \pm 1^{\circ} \mathrm{C}$ for only 3 days.

\section{Canning process}

Washed fish were de-headed, eviscerated, trimmed of fins and cut into steaks $(3 \mathrm{~cm}$ long) then quickly washed under running water. The steaks were immersed in $10 \%$ brine solution for $10 \mathrm{~min}$, and then steamed at atmospheric pressure for $15 \mathrm{~min}$. The steamed steaks were packed into glass jars, then hot oil, brine $(3 \%)$ or sauce $(8 \%$ Total soluble solids) was added before jars were exhausted and lids sealed immediately. The closed glass jars were transferred into a vertical retort and treated under pressure $\left(15 \mathrm{lb} / \mathrm{in}^{2}\right)$ for $60 \mathrm{~min}$. After the heat processing step, the jars were cooled immediately and stored at room temperature for 7 days.

\section{Analysis}

Fish fillets were prepared from fresh fish (20 samples), salted fish (20 samples), with each sample representing one single fish. Marinated fish fillets (20 samples) were selected randomly from different jars. Canned fish steaks ( 7 samples) were selected from each of the filling media (vegetable oil, brine or tomato sauce) to represent 21 total canned fish samples. Samples were then prepared for the following assessments.

\section{pH measurement}

Fish samples were blended with distilled water at a ratio of 1:9 (W/V). The $\mathrm{pH}$ of the solution was determined by a calibrated $\mathrm{pH}$ meter (PH700 Benchtop, Apera Instruments, LLC) according to AOAC (1995).

\section{Bacterial detection and enumeration}

For bacterial counts, samples ( $25 \mathrm{~g}$ each) were diluted in $225 \mathrm{ml} 0.1 \%$ sterilised peptone water (Lab M, Lancashire, UK) and stomached for 2 minutes. From this dilution, other serial dilutions were prepared. Aerobic colony counts were determined by the spread plate method, using nutrient agar (Lab M, Lancashire, UK). Xylose lysine deoxycholate agar (XLD, Lab M, Lancashire, UK) was used for enumerating and isolating Salmonella spp. Plates were incubated at $37^{\circ} \mathrm{C}$ for $24 \mathrm{~h}$ and the colony forming units (CFU/g) were counted (Al-Harbi and Uddin, 2005; Santo et al, 2008). Colonies with different morphologies from nutrient and XLD media were streaked on trypticase soy agar (TSA, Lab M, Lancashire, UK) slants and subjected to biochemical tests, triple sugar iron and identification with API 20E diagnostic strips (Biomérieu, France) as described in published reports (Food and Drug Administration, FDA, 1998; Angela Di Pinto et al., 2008).

For counting and isolation of Vibrio spp., fish flesh samples ( $25 \mathrm{~g}$ each) were added to a sterile bag with $225 \mathrm{ml}$ of alkaline peptone water (APW, Lab M, Lancashire, UK) with $\mathrm{pH} 8.6$, containing $1 \% \mathrm{NaCl}$, stomached for 2 min and incubated overnight at $37^{\circ} \mathrm{C}$. Aerobic colony counts were determined by the spread plate method onto thiosulphate-citrate-bile salts-sucrose (TCBS, Lab M, Lancashire, UK) agar plates containing $1 \% \mathrm{NaCl}$. Green, blue-green and yellow colonies on TCBS agar plates were presumptively selected as Vibrio colonies and transferred to 
TSA slants (Lab M, Lancashire, UK) with 2\% NaCl (Di Pinto et al., 2008). After incubation, isolates with different morphologies were subjected to the oxidase test using oxidase sticks (Oxoid, Hampshire, UK) and biochemical identification with API 20E as described by the FDA (1998).

\section{Bacterial Identification by sequencing of $16 \mathrm{~S}$ rDNA}

This technique was applied for confirmation of API results and for the identification of unknown bacteria samples. It was performed as described by Janda and Abbott (2007).

\section{Amplification of 16S rDNA}

DNA extraction was done using a bacterial DNA preparation kit (Jena Bioscience, Thuringia, Germany). Partial 16S rDNA was amplified using universal oligonucleotides primers (Forward: 5'-GAGTTTGATCCTGGCTTAG-3'and Reverse: 5'-GGTTACCTTGTTACGACTT-3'). Briefly, $2 \mu$ DNA templates (20 ng/ $\mu \mathrm{l}$ ) was added to $12.5 \mu \mathrm{l}$ Master Mix (Qiagen, Hilden, Germany) and $10.5 \mu \mathrm{l}$ deionised water $\left(\mathrm{H}_{2} \mathrm{O}\right)$ for a total volume of $25 \mu \mathrm{l}$. The mixture was then amplified in a DNA thermal cycler (Techne Progene, Marshall Scientific, Hampton, NH) using the following program: one denaturation step at $94^{\circ} \mathrm{C}$ for $5 \mathrm{~min} ; 37$ cycles $\left(30 \mathrm{~s}\right.$ at $94^{\circ} \mathrm{C}$, $30 \mathrm{~s}$ at $51^{\circ} \mathrm{C}$ and $30 \mathrm{~s}$ at $72^{\circ} \mathrm{C}$ ); and a final extension for $5 \mathrm{~min}$ at $72^{\circ} \mathrm{C}$.

Gel preparation and analysis of the PCR products were performed by gel electrophoresis using $1.5 \%$ agarose gel with $1 \mathrm{X}$ TAE buffer.

\section{DNA Sequencing}

Purification of the PCR products was performed using a QIAquick Kit (Qiagen, Hilden, Germany). The second PCR was performed using a BigDye Terminator v3.1 Cycle Sequencing Kit (ThermoFisher, MA, USA). Each reaction $(20 \mu \mathrm{l})$ contained Terminator ready reaction mix $(8 \mu \mathrm{l})$, primer $(3.2 \mathrm{pmol})$, DNA template quantised according to the PCR product size and deionised water. The thermal profile for cycle sequencing PCR was $1 \mathrm{~min}$ at $96^{\circ} \mathrm{C} ; 25$ cycles as follows: $10 \mathrm{~s}$ at $96^{\circ} \mathrm{C}, 5 \mathrm{~s}$ at $50^{\circ} \mathrm{C}$ and $4 \mathrm{~min}$ at $60^{\circ} \mathrm{C}$. After an additional purification step using CENTRI-SEP Columns (PrincetonSeparations, Freehold, NJ), DNA sequencing was carried out by a 3500 Genetic Analyzer (Applied Biosystems, Massachusetts, USA). The obtained consensus sequences were subjected to a BLAST search through the Mega program (7.0.20) as described by Azwai1 et al.(2016).

\section{Heavy Metals Analysis}

Muscle tissues $(0.5 \mathrm{~g})$ of the samples, triplicate samples from each treatment group, were placed into a screw digestion cup before adding nitric acid $\left(\mathrm{HNO}_{3}, 5 \mathrm{ml}\right)$ and perchloric acid $\left(\mathrm{HClO}_{4}, 2 \mathrm{ml}\right)$ (UNEP/FAO/IAEA/IOC, 1984).Mixtures were heated at $80^{\circ} \mathrm{C}$ until completely dissolved. After cooling to room temperature, the content was decanted into falcon tubes and the total volume of the sample was made to $25 \mathrm{ml}$ using ultra-pure water. The concentrations of cadmium $(\mathrm{Cd})$, chromium $(\mathrm{Cr})$, copper $(\mathrm{Cu})$, nickel $(\mathrm{Ni})$ and lead $(\mathrm{Pb})$ in the digested samples were determined using an Atomic Absorption Spectrophotometer, Shimadzu 6800 (UNEP/FAO/IAEA/IOC, 1984).

Mercury $(\mathrm{Hg})$ analysis was conducted using cold vapor atomic absorption. Dried samples $(0.5 \mathrm{~g})$ were weighed, mixed with $\mathrm{HNO}_{3}(5 \mathrm{ml})$ and $\mathrm{HClO}_{4}(2 \mathrm{ml})$ then heated at $40^{\circ} \mathrm{C}$ until the samples were dissolved. After cooling at room temperature, ultra-pure water was added to the samples to make the volume $25 \mathrm{ml}$. Cold vapor atomic absorption spectroscopy was used to determine $\mathrm{Hg}$ concentration in the digested sample and the analysis was carried out in triplicate samples (UNEP/IAEA 1984). 
Standard reference material (DORM-4: fish protein, the National Research Council of Canada) was used to validate the analysis. Mean recoveries of $\mathrm{Hg}, \mathrm{Cd}, \mathrm{Cr}$, $\mathrm{Pb}, \mathrm{Cu}$ and $\mathrm{Ni}$ were 96.8, 95.4, 96.1, 95.2, 106.2 and 95.3\%, respectively.

\section{Statistical Analysis}

Statistical analysis was performed using Minitab® Software (Version 16.0, Minitab Inc., Pennsylvania, USA). All measurements were carried out using seven independent replicate samples. One-way analysis of variance (ANOVA) was used to determine the effects of processing on the measured parameters. Significant differences among the means were determined using Tukey multiple comparison tests in the general linear model (GLM) protocol at a confidence level of 95\% (P<0.05).

\section{RESULTS AND DISCUSSION}

\section{Microbiological analysis \\ Aerobic colony counts}

Aerobic colony counts (ACC) in fresh chilled fish samples $\left(5.1 \pm 0.2 \log _{10}\right.$ $\mathrm{CFU} / \mathrm{g}$ ) were within the acceptable limits compared to the Egyptian Organisation for Standardisation, EOS $\left(<10^{6} \mathrm{CFU} / \mathrm{g}, \mathrm{EOS}, 2005\right)$, as shown in Table1. Marinating and salting processes decreased the total count to $1.1 \pm 0.3$ and $3.8 \pm 0.2 \log _{10} \mathrm{CFU} / \mathrm{g}$, respectively, demonstrating a reduction of $4 \operatorname{logs}$ detected for fish marinated with $2.5 \%$ acetic acid and $3 \% \mathrm{NaCl}$ while salting reduced the bacterial count by 1.3 logs. The higher reduction in ACC of the marinated fish might be due to combined actions of steaming and the presence of acid and salt in the marinating solutions compared to the effect of salt only at high $\mathrm{pH}$ (6.5) in the salted fillet. Similar results of ACC reduction of 1.58 and $1.76 \operatorname{logs}$ were detected in Pacific saury fish marinated with pre-chilled $2 \%$ acetic acid or $3 \%$ acetic acid and $12 \%$ salt, respectively at the end of three months storage (Sallam, 2008). Ozogul et al. (2009) reported a reduction in ACC after 90 days (0.3 log reduction, from 3.5 to $3.2 \log$ CFU/g) in Tench after application of warm marinating process with a $4 \%$ acetic acid solution. Marinating seabass using $0.1 \%$ citric acid and $8 \% \mathrm{NaCl}$ at $4^{\circ} \mathrm{C}$ was reported to reduce the number of enterobacteria and hydrogen sulfide $\left(\mathrm{H}_{2} \mathrm{~S}\right)$-producing bacteria over 3 days of storage, while with prolonged storage, ACC and lactic acid bacteria were slightly increased (Giuffrida et al., 2007). On the other hand, Shiriskar et al. (2009) reported an increase in the total bacterial count of pickled anchovy from an initial value of $4.85 \times 10^{1}$ to $3.0 \times 10^{5} \mathrm{CFU} / \mathrm{g}$ after 15 weeks of storage. The fast marinating time trial in this study (only 3 days) was not enough for deep penetration of the acid into the fish flesh, as the $\mathrm{pH}$ values of marinating solution and marinated flesh were 4.0 and 5.5, respectively; this suggests potential for further reduction upon extended storage. The low $\mathrm{pH}$ of the solution might explain the absence of bacterial growth. Sallam (2008) reported that ACC was significantly $(\mathrm{P}<0.05)$ decreased in marinated Pacific saury fish fillet after 40 days of storage.

Table 1: Aerobic colony count $\log _{10}(\mathrm{CFU} / \mathrm{g})$ and $\mathrm{pH}$ results of fresh fish and processed fish products

\begin{tabular}{|c|c|c|c|c|c|c|c|}
\hline & Fresh & \multicolumn{2}{|c|}{ Marinated } & Salted & \multicolumn{3}{c|}{ Canned } \\
\cline { 3 - 8 } & & $\begin{array}{c}\text { Marinated } \\
\text { fish }\end{array}$ & $\begin{array}{c}\text { Marinated } \\
\text { solution }\end{array}$ & & $\begin{array}{c}\text { Tomato } \\
\text { sauce }\end{array}$ & Brine & Oil \\
\hline Total plate count & $5.1 \pm 0.2$ & $1.1 \pm 0.3$ & $<1$ estimated & $3.8 \pm 0.2$ & $<1$ estimated & $<1$ estimated & $<1$ estimated \\
\hline Salmonella spp. & $4.1 \pm 0.1$ & $1.0 \pm 0.1$ & $<1$ estimated & $2.3 \pm 0.4$ & $<1$ estimated & $<1$ estimated & $<1$ estimated \\
\hline Vibrio spp. & $4.4 \pm 0.3$ & $<1$ estimated & $<1$ estimated & $3.7 \pm 0.2$ & $<1$ estimated & $<1$ estimated & $<1$ estimated \\
\hline $\mathrm{pH}$ & $6.5 \pm 0.1$ & $5.5 \pm 0.1$ & $4.0 \pm 0.1$ & $6.5 \pm 0.1$ & $4.8 \pm 0.1$ & $5.1 \pm 0.1$ & $4.9 \pm 0.1$ \\
\hline
\end{tabular}

The values represent the means of seven independent samples $(n=7) \pm$ standard deviation. 
In the canning process, fish were exposed to extensive thermal treatment that led to no detection of bacterial growth. Excluding anomalies in the thermal treatment process of canned fish products and any contamination after treatment, the canned fish product should be safe for consumption. Casalinuovo et al. (2015) reported that contaminations in canned products were most likely due to inappropriate production quality standards and/or the quality of the raw material used. Our results show that even with high total count raw material, canning can help to improve the microbial count of the fish.

\section{Salmonella}

Salmonella is often the etiological agent of gastroenteritis associated with the consumption of contaminated fish (Rahimi et al., 2013). It is well established that aquatic birds, raw sewage and pre-harvest contamination from animal and human reservoirs can spread salmonellae and other human pathogens into seafood (Huss et al., 2000). Salmonella enterica Ras3 was isolated from fresh fish, identified, sequenced and represented in a phylogenic tree in Figure1. The nucleotide sequence of $S$. enterica Ras 3 was submitted to Gen-Bank and has been provided by accession number KY120327. S.enterica has been reported in different types of fish in different countries: in freshly caught tilapia and catfish in Malaysia; whiting fish in France; European plaice, Atlantic salmon and rainbow trout in Great Britain; European pilchard Portugal; and Nile tilapia in Egypt (Youssef et al., 1992; Pullela et al., 1998; Davies et al., 2001; Budiati et al., 2013; Novoslavskij et al., 2016). According to EOS standards, Salmonella should not be found in chilled fresh fish and its presence in samples in the present study suggests better control and monitoring is required (EOS, 2005).

Table 2: Identification of selected colonies based on API 20E biochemical tests

\begin{tabular}{|c|c|c|}
\hline Fresh fish & Marinated fish & Salted fish \\
\hline Enterobacter cloacae & - & - \\
\hline Salmonella enterica & Citrobacter koseri & - \\
\hline Pasteurella pneumotropica & - & Shewanella putrefaciens \\
\hline
\end{tabular}

Processing of fish is an important step to improve food safety. Salmonella was not found in any of the processed fish products (marinated, salted or canned fish products). Low ACC (1 log CFU/g) was found on XLD agar for marinated fish. All presumptive colonies were selected and some were identified as Citrobacter koseri (Table2). Ozogul et al. (2008) reported similar results, where Salmonella and other pathogenic bacteria were not detected in marinated fish products while aerobic colony counts remained at $3 \operatorname{logs} \mathrm{CFU} / \mathrm{g}$ after 3 months of storage. In the salted fish product, the aerobic colony counts were $2.3 \mathrm{logs}$ CFU/g on XLD agar, but no Salmonella was found. In contrast, Arkoudelos et al. (2003) reported that S.enteritidis survived for 90 days in salted sardines during ripening. Similarly, S. enteritidis survived in salted horse mackerel fillets after 60 days of salting (salt/fish=80/100) and 65 days (salt/fish $=30 / 100)$ during storage at $4^{\circ} \mathrm{C}$ (Mol et al., 2010). The differences in the processing (samples were air dried in Mol et al. (2010) compared with vacuuming the samples and retaining any exudates in the present study), the high inoculation count in Arkoudelos et al. (2003) and Mol et al. (2010) or the analysis (XLD was used in all studies, but confirmation using 16S rDNA was done in the present study only) may explain the differences observed. 


\subsubsection{Vibrio}

Vibrio spp. are major food-borne pathogens. High levels of Vibrio contamination in raw seafood may be expected because of natural contamination from the aquatic environment. $V$. parahaemolyticus is frequently isolated and reported from seafood in various countries (Wong et al., 1999; Basti et al., 2006; Nakaguchi, 2013; Novoslavskij et al., 2016).

In this study, high ACC were observed on TCBS medium with fresh fish (4.4 $\operatorname{logs}$ CFU/g) and salted fish (3.7 logs CFU/g), as shown in Table1. The ACC in salted fish might be due to the growth of halophilic bacteria after 2 weeks storage (Ali, 2012). All suspected colonies were isolated and identified as Pasteurella pneumotropica in fresh fish and Shewanella putrefaciens in salted fish, with a complete absence of Vibrio species (Table2). Ekhtiarzadeh et al. (2012) reported that the growth of $V$. parahaemolyticus was inhibited in salted fish fillets (brine salted at $4 \% \mathrm{NaCl}$ ) at $8^{\circ} \mathrm{C}$, with a reduction from $3 \log \mathrm{CFU} / \mathrm{g}$ to $<2 \log \mathrm{CFU} / \mathrm{g}$ at the first day of study. The results of this study are in contrast with reports of long-term survival of Vibrio spp. at salt concentrations similar to those of the seawater environment $(3.3 \%)$ (Armada et al., 2013), salted herring (6.2\%) and salted roe samples (1.3\%) (Chiţu et al., 1977). No viable bacterial colonies were detected in marinated and canned products. Sallam et al. (2008) reported similar results where Vibrio was not detected in marinated Pacific saury treated with marinating solutions containing either $12 \%$ $\mathrm{NaCl}$ and $2 \%$ acetic acid or $12 \% \mathrm{NaCl}$ and 3\% acetic acid and stored at $4{ }^{\circ} \mathrm{C}$ for 90 days. $V$. parahaemolyticus was also reported to be reduced to below detection limits ( $~ 5-\log$ reduction) with the use of lime juice for marinating (Mathurand et al., 2013). Finally, there are no records of association of Vibrio spp.with canned food.

\section{Heavy metals}

The heavy metals concentrations of fresh, dry-salted, hot-marinated and canned fish in oil, brine or tomato sauce are shown in Table 3. The average concentrations of $\mathrm{Hg}, \mathrm{Cd}, \mathrm{Cr}, \mathrm{Pb}, \mathrm{Cu}$ and $\mathrm{Ni}$ in fresh fish were below the limit of detection (LOD): $0.16,0.38,0.92,2.25$, and $0.55 \mu \mathrm{g} / \mathrm{g}$, respectively. After processing, the averages of these heavy metals ranged from LOD to $0.01,0.11$ to $0.15,0.30$ to $0.39,0.83$ to 0.91 , 2.20 to 2.27 and 0.41 to $0.54 \mu \mathrm{g} / \mathrm{g}$ for $\mathrm{Hg}, \mathrm{Cd}, \mathrm{Cr}, \mathrm{Pb}, \mathrm{Cu}$ and $\mathrm{Ni}$, respectively (Table $3)$. In general, hot marinating, dry salting and canning tended to decrease the means of all determined heavy metals, probably due to loss of minerals to the liquids used in processing or the salting out and subsequent proteolysis that occured during salting for two weeks. These reductions were significant only in $\mathrm{Cr}$ and $\mathrm{Ni}$ (Table 3).

Table 3: Effects of processing methods on heavy metal concentrations ( $\mu \mathrm{g} / \mathrm{g} \mathrm{wt})$ in processed Indian mackerel

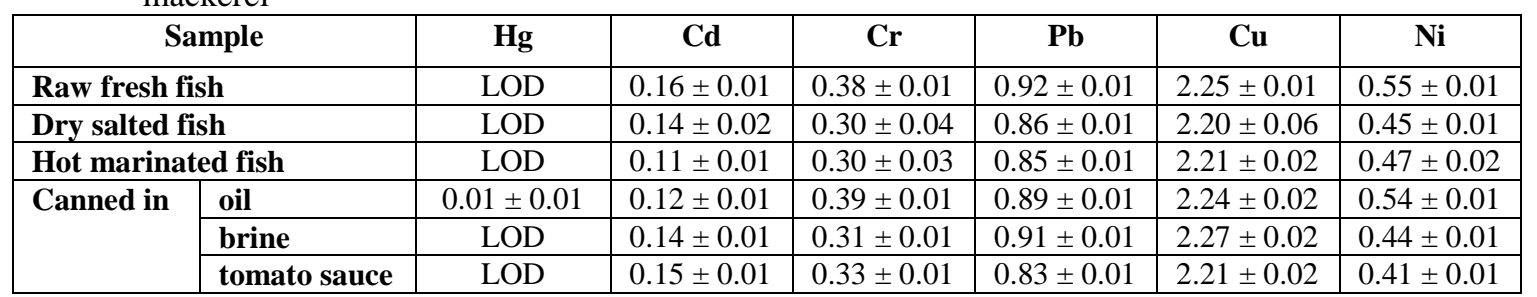

LOD = below level of detection.

The values represent the means of seven independent samples $(n=7) \pm$ standard error of the means.

According to the legal standard recommended by the European Commission (EC, 2001), EOS (2004) and FAO (1983), raw fresh fish and their product samples exceeded the maximum residue levels (MRLs) for their $\mathrm{Pb}$ and $\mathrm{Cd}$ contents (0.5 and 
$0.1 \mathrm{ppm}$, respectively). This is of concern, considering that $\mathrm{Pb}$ and $\mathrm{Cd}$ are toxic and that their accumulation may lead to human health hazards, especially for children.

Lead and $\mathrm{Cd}$ are among of the most toxic, widely-distributed metals that accumulate in the food chain and are easily absorbed during digestion (Krejpcio and Trojanowska, 2000; Dermirezen and Uruç, 2006). Berny et al. (1994) and the Commission of the European Communities (2001) stated that these metals can cause serious health problems. $\mathrm{Pb}$ may cause problems in the nervous and urinary systems and inhibit heme synthesis, while Cd may lead to the development of prostate and breast cancer and skeletal abnormalities (Nordberg et al., 2002; Saha and Zaman, 2012).

In Egypt between 1996 and 2010 fish consumption increased from $8.5 \mathrm{~kg}$ to $16.7 \mathrm{~kg} /$ person/year (FAO, 2010). According to the FAO (2010), the average quantity of fish consumed per person (assuming a $70 \mathrm{~kg}$ person) per day in Egypt was 45.75 $\mathrm{g} /$ person/day. The estimated daily intakes (EDI) or weekly intakes (EWI) and EWI/provisional tolerable weekly intake (PTWI) ratio for $\mathrm{Pb}$ and $\mathrm{Cd}$ in fresh and processed fish products are shown in Table 4. The EDI or EWI for $\mathrm{Pb}$ and $\mathrm{Cd}$ in fish samples in this study were estimated according to the following equation:

$$
\mathrm{EDI}=\mathrm{C}_{\text {metal }} \times \mathrm{W} / \mathrm{bw}
$$

Where $\mathrm{C}_{\text {metal }}$ is the average concentration of $\mathrm{Pb}$ and $\mathrm{Cd}$ in fish; $\mathrm{W}$ represents the daily average consumption of marine fish; and bw is body weight, set to $70 \mathrm{~kg}$. PTWI standard levels were provided by the European Food Safety Authority (EFSA, 2009 \& 2010). The results of EWI and EDI values were below the recommended EFSA values for $\mathrm{Pb}$ and $\mathrm{Cd}(25$ and $2.5 \mu \mathrm{g} / \mathrm{kg}$ bw, respectively) (Table4).

Table 4: The estimated daily intake (EDI, $\mu \mathrm{g} / 70 \mathrm{~kg}$ bw/day) and estimated weekly intake $(\mathrm{EWI}, \mu \mathrm{g} / 70 \mathrm{~kg} \mathrm{bw} / \mathrm{week})$ and estimated weekly intake/provisional tolerable weekly intake (EWI/PTWI) ratio of $\mathrm{Pb}$ and $\mathrm{Cd}$ of fresh fish and canned fish in oil, brine and tomato sauce

\begin{tabular}{|c|c|c|c|c|c|c|c|c|c|}
\hline \multirow{2}{*}{\multicolumn{2}{|c|}{ Sample }} & \multicolumn{4}{|c|}{$\mathbf{P b}$} & \multicolumn{4}{|c|}{ Cd } \\
\hline & & Conc. & EDI & EWI & $\begin{array}{l}\text { EWI/ } \\
\text { PTWI }\end{array}$ & Conc. & EDI & EWI & $\begin{array}{l}\text { EWI/ } \\
\text { PTWI }\end{array}$ \\
\hline \multicolumn{2}{|c|}{ Raw fresh fish } & 0.92 & 0.32 & 2.21 & 0.09 & 0.16 & 0.05 & 0.38 & 0.15 \\
\hline \multicolumn{2}{|c|}{ Raw fresh fish } & 0.86 & 0.29 & 2.06 & 0.08 & 0.14 & 0.05 & 0.34 & 0.13 \\
\hline \multicolumn{2}{|c|}{ Hot marinated fish } & 0.85 & 0.29 & 2.04 & 0.08 & 0.11 & 0.04 & 0.26 & 0.11 \\
\hline \multirow[t]{3}{*}{ Canned in } & oil & 0.89 & 0.31 & 2.14 & 0.09 & 0.12 & 0.04 & 0.29 & 0.12 \\
\hline & brine & 0.91 & 0.31 & 2.18 & 0.09 & 0.14 & 0.05 & 0.34 & 0.13 \\
\hline & tomato & 0.83 & 0.28 & 1.99 & 0.08 & 0.15 & 0.05 & 0.36 & 0.14 \\
\hline
\end{tabular}

Calculated from the EFSA values, 25 and $2.5 \mu \mathrm{g} / \mathrm{kg}$ bw, respectively.

The EWI/PTWI ratios for $\mathrm{Pb}$ and $\mathrm{Cd}$ in fish samples were below 1, which means that the results remained within the established safety regulations for humans. The results of this study agree with those of Elisavet et al. (2014), who found that in Egypt the mean values for $\mathrm{Pb}$ and $\mathrm{Cd}$ content in demersal fish (1.74 and not recorded (NR) $\mu \mathrm{g} / \mathrm{g}$, respectively), pelagic fish (1.7 and $0.19 \mu \mathrm{g} / \mathrm{g}$, respectively) and marine fish (1.46 and $0.75 \mu \mathrm{g} / \mathrm{g}$, respectively) were high. The EWI values were also high (2.09 and NR; 1.70 and 0.19; and 0.87 and $0.45 \mu \mathrm{g} / \mathrm{week} / 70 \mathrm{~kg} \mathrm{bw}$ ) in demersal, pelagic and marine fish, respectively, while the EWI/PTWI data ratios were low $(0.08$ and NR; 0.07 and 0.08; and 0.03 and 0.18 , respectively). 


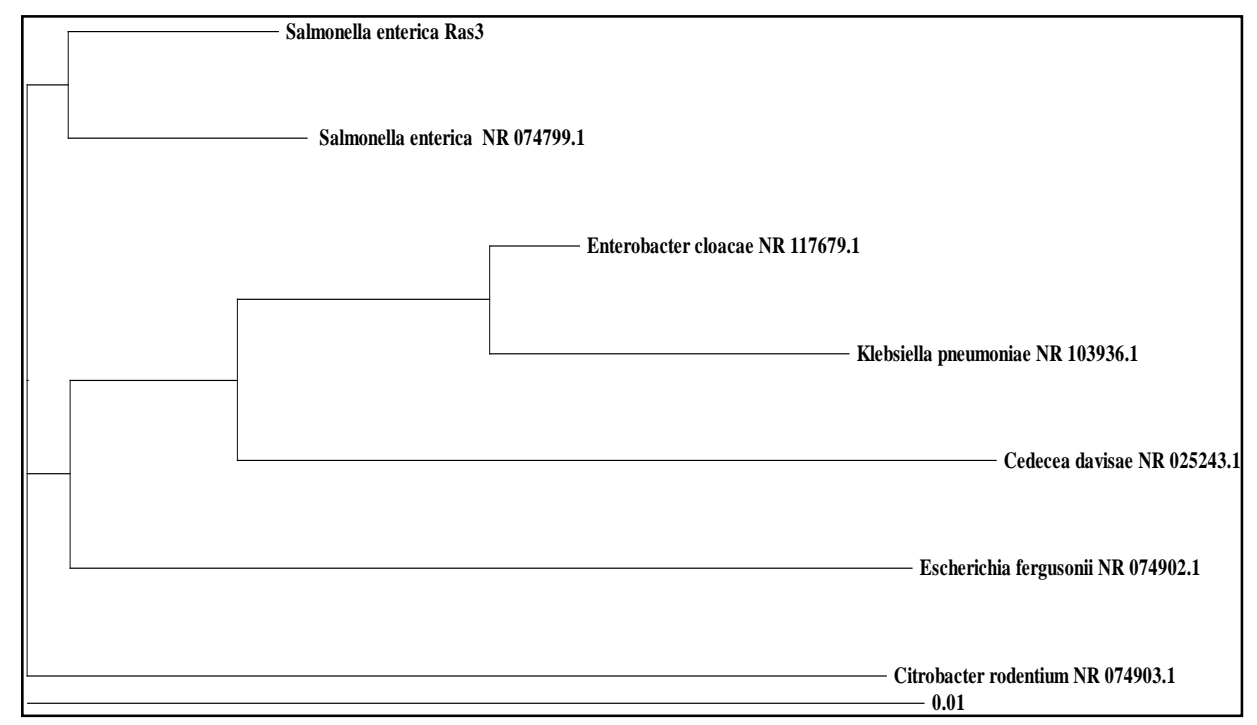

Fig. 1: Phylogenic tree of sequenced Salmonella enterica RAS3.

\section{CONCLUSION}

This study showed that the processing of Indian mackerel fish (cascomry) by salting (using 15\%dry salt) and the hot marinating process (steaming and marinating in a solution containing $2.5 \%$ acetic acid and $3 \% \mathrm{NaCl}$ ) improved the microbiological quality of the product and inhibited the growth of food-borne pathogens. Canning with hot oil, brine $(3 \%)$ or sauce $(8 \%$ TSS) eliminated all viable bacterial growth. Moreover, processing did not cause an increase in heavy metal content compared to fresh fish. Fresh fish and their products exceeded the maximum standard residue levels for $\mathrm{Pb}$ and $\mathrm{Cd}$ contents; however, results of estimated daily and weekly values were below the recommended safety margins for human consumption. Therefore, these fast processing techniques can be used as safe methods for the preservation of cascomry fish in Egypt.

\section{REFERENCES}

Ali, M. (2012). Shelf life determination of the brined golden mullet Liza aurata during vacuum refrigerated storage using some quality aspect. Acta Scientiarum Polonorum Technologia Alimentaria. 11: 37-43.

Al-Harbi, A. and Uddin, N. (2005). Bacterial diversity of tilapia (Oreochromis niloticus) cultured in brackish water in Saudi Arabia. Journal of Aquaculture. 250: 566-572.

Arkoudelos, J.S.; Samaras, F.J. and Tassou, C.C. (2003). Survival of Staphylococcus aureus and Salmonella enteritidis on salted sardines (Sardina pilchardus) during ripening. Journal of Food Protection. 66: 1479-1481.

Armada, S.P.; Farto, R.; Pérez, M.J. and Nieto, T.P. (2003). Effect of temperature, salinity, and nutrient content on the survival responses of Vibrio splendidus biotype I. Journal of Microbiology. 149: 369-375.

Association of Official Analytical Chemists.(1995). Official Methods of Analysis, Association of Analytical Chemists. Washington, DC.

Azwai1, S.M.; Alfallani, E.A.; Abolghait, S.K.; Garbaj, A.M.; Naas, H.T.; Moawad, A.A.; Gammoudi, F.T.; Rayes, H.M.; Barbieri, I. and Eldaghayes, I.M. (2016). 
Isolation and molecular identification of Vibrio spp. by sequencing of $16 \mathrm{~S}$ rDNA from seafood, meat and meat products in Libya. Open Veterinary Journal. 6: 36-43.

Basti, A.A.; Misaghi, A.; Salehi, T.Z. and Kamkar, A. (2006). Bacterial pathogens in fresh, smoked and salted Iranian fish. Food Control. 17: 183-188.

Budiati, T.; Rusul, G.; Wan-Abdullah,W.N.; Arip, Y.M.; Ahmad, R. and Thong, K.L. (2013). Prevalence, antibiotic resistance, and plasmid profiling of salmonella in catfish (Clarias gariepinus) and tilapia (Tilapia mossambica) obtained from wet markets and ponds in Malaysia. Aquaculture Journal. 372: 127-132.

Casalinuovo, F.; Gazzotti, T.; Rippa, P.; Ciambrone, L.; Musarella, R. and Pratticò, E. (2015). Microbiological stability of canned tuna produced in Italy and in non-European countries. Italian Journal of Food Safety. 4: 4776-4780.

Chițu, M.; Ciufecu, C. and Năcescu, N. 1977. The isolation and characterization of some Vibrio parahaemolyticusstrains isolated from salted herring and roe. Zentralblatt für Bakteriologie, Parasitenkunde, Infektionskrankheiten und Hygiene. 238: 59-65.

Davies, A.R.; Capell, C.; Jehanno, D.; Nychas, G.J.E. and Kirby, R.M. (2001). Incidence of foodborne pathogens on European fish. Food Control. 12: 67-71.

Di Pinto, A.; Giuseppina, C.; Rita, D.C.; Lucia, N. and Valentina, T.2008. Detection of pathogenic Vibrio parahaemolyticus in southern Italian shellfish. Food Control. 19: 1037-1041.

Ekhtiarzadeh, H.; Basti, A.A.; Misaghi, A.; Sari, A.; Khanjari, A.; Rokni, N.; Abbaszadeh, S. andPartovi, R. (2012). Growth response of Vibrio parahaemolyticus and Listeria monocytogenes in salted fish fillets as affected by Zataria multiflora Boiss, essential oil, nisin, and their combination. Journal of Food Safety.32: 263-269.

El Zokm, G.M.; Okbah, M.A. and Younis, A.M. (2015). Assessment of Heavy Metals Pollution Using AVS-SEM and Fractionation Techniques in Edku Lagoon Sediments, Mediterranean Sea, Egypt. Journal of Environmental Science and Health, Part A, 50: 1-14.

Emami-Khansari, F.; Ghazi-Khansari, M. and Abdollahi, M. (2005). Heavy metals content of canned tuna fish. Food Chemistry. 93: 293-296.

Egyptian Organization for Standardization and Quality Control, E.O.S. (2005). Bacteriological standardization for chilled fish. Ministry of Industry and Technological Development, Egypt.3494.

FAO/WHO.(2004). Summary of evaluations performed by the joint FAO/WHO Expert Committee on Food Additives (JECFA 1956-2003) (First through sixtyfirst meetings). Food and Agriculture Organization of the United Nations and the World Health Organization, ILSI Press International Life Sciences Institute, Washington, DC.

FDA. (1998). Vibrio cholerae, V. parahaemolyticus, V. vulnificus and Other Vibrio spp. Bacteriological Analytical Manual.8th Ed.

Giuffrida, A.; Ziino, G.; Orlando, G. and Panebianco, A. (2007). Hygienic evaluation of marinated sea bass and challenge test for Listeria monocytogenes. Veterinary Research Communications. 31: 369-371.

Huss, H.H.; Reilly, A. and Ben Embarek, K. (2000). Prevention and control of hazards in seafood. Food Control. 11: 149-156.

Janda, J.M. and Abbott, S.L. (2007). 16S rRNA gene sequencing for bacterial identification in the diagnostic laboratory: pluses, perils and pitfalls. Journal of Clinical Microbiology. 45: 2761-2764. 
Kalay, M.; Aly, O. and Canil, M. (1999). Heavy metal concentrations in fish tissues from the Northeast Mediterranean Sea. Bulletin of Environmental Contamination and Toxicology. 63: 673-681.

Mathurand, P.I. and Schaffner, D.W. (2013).Effect of lime juice on Vibrio parahaemolyticus and Salmonella enterica inactivation during the preparation of the raw fish dish ceviche. Journal of Food Protection. 76: 1027-1030.

Mol, S.I.; Cosansu, S.; Ucok Alakavuk, D. and Ozturan, S. (2010). Survival of Salmonella enteritidis during salting and drying of horse mackerel (Trachurus trachurus) fillets. International Journal of Food Microbiology. 139: 36-40.

Mol, S. and Tosun, S.Y. (2011). The quality of fish from retail markets in Istanbul, Turkey. Journal of Fisheries Sciences. 5: 16-25.

Molina-Höppner, A.; Doster, W.; Vogel, R.F. and Gänzle, M.G. (2004). Protective effect of sucrose and sodium chloride for Lactococcus lactis during sub-lethal and lethal high-pressure treatments. Applied and Environmental Microbiology. 70: 2013-2020.

Nakaguchi, Y. (2013). Contamination by Vibrio parahaemolyticus and its virulent strains in seafood marketed in Thailand, Vietnam, Malaysia and Indonesia. Tropical Medicine and Health. 41: 95-102.

Novoslavskij, A.; Terentjeva, M.; Eizenberga, I.; Valciņa, O.; Bartkevičs, V.and Bērziņš, A. (2016). Major foodborne pathogens in fish and fish products: a review. Annals of Microbiology. 66: 1-15.

Özogul, Y.; Kuley, E. and Özogul, F. (2009). Quality changes of marinated Tench (Tinca tinca) during refrigerated storage. Journal of Food Science and Technology International. 15: 513-521.

Ö zogul, Y.1.; Ö zogul, F.; Olgunoglu, I.A. and Kuley, E. (2008). Bacteriological and biochemical assessment of marinating cephalopods, crustaceans and gastropodaduring 24 weeks of storage. International Journal of Food Science and Nutrition.59: 465-76.

Oxen, P. and Knorr, D. (1993). Baroprotective effects of high solute concentrations against inactivation of Rhodotorula rubra. Food Science and Technology International. 26: 220-223.

Pullela, S.; Fernandes, C.F.; Flick, G.J.; Libey, G.S.; Smith, S.A. and Coale, C.W. (1998). Indicative and pathogenic microbiological quality of aquacultured finfish grown in different production systems. Journal of Food Protection. 61: 205-210.

Rahimi, E.; Shakerian, A. and Falavarjani, A.G. (2013). Prevalence and antimicrobial resistance of Salmonella isolated from fish, shrimp, lobster and crab in Iran. Comparative Clinical Pathology. 22: 59-62.

Said, T.O.; Farag, R.S.; Younis, A.M.; Shreadah, M.A. (2006). Organotin Species in Fish and Bivalves Samples Collected from the Egyptian Mediterranean Coast of Alexandria, Egypt. Bulletin of Environmental Contamination and Toxicology, 77: 451-458.

Sallam K.I. (2008). Effect of marinating process on the microbiological quality of Pacific saury (Cololabis saira) during vacuum packaged storage at $4{ }^{\circ} \mathrm{C}$. International Journal of Food Science and Technology. 43: 220-228.

Santo, M.L.; Vivian, V.; Mirapalheta, T.; Carbonera, N.; Coelho, G. and Damian, C. (2008). Chemical, physical and microbiological changes in tilapia (Oreochromis niloticus) during marination. Alimentos e Nutrição. 18: 1-4. 
Shiriskar, D.A.; Khedkar, G.D. and Sudakarn, N.S. (2009). Preparation of pickled product from anchovies (Stolephorus sp.) and studies on quality changes during storage. Journal of Food Processing and Food Preservation. 34: 176-190.

Sevenich, R.; Bark, F.; Crews, C.; Anderson, W.; Pye, C.; Riddellova, K.; Hradecky, J.; Moravcova, E.; Reineke, K. and Knorr, D. (2013). Effect of high pressure thermal sterilization on the formation of food processing contaminants. Innovative Food Science \& Emerging Technologies.20: 42-50.

Shamsuzzaman, M.M.; Mazumder, S.K.; Siddique, M.A. andMiah, M.N.U. (2011). Microbial quality of hilsa shad (Tenualosa ilisha)at different stages of processing. Journal of the Bangladesh Agricultural University. 9: 339-344.

Shreadah, M.A.; Said, T.O., Younis, A.M.; Farag, R.S. (2006). Speciation of Organotin Compounds in Sediments of Semi-Closed Areas along the Mediterranean Coast of Alexandria," Chemistry and Ecology, 22 (5): 395-404.

Soliman N. F., Younis, A.M., Elkady E. M. \& Mohamedein L. I. (2018): Geochemical associations, risk assessment, and source identification of selected metals in sediments from the Suez Gulf, Egypt, Human and Ecological Risk Assessment: An International Journal, DOI: 10.1080/10807039.2018.1451301.

Song, Y.; Luo, Y.; You, J.; Shen, H. and Hu, S. (2011). Biochemical, sensory and microbiological attributes of bream (Megalobrama amblycephala) during partial freezing and chilled storage.Journal of the Science of Food and Agriculture. 92: 197-202.

Van-Opstal, I.; Vanmuysen, S.C.M. and Michiels, C.W. (2003). High sucrose concentration protects $E$. coli against high pressure inactivation but not against high pressure sensitization to the lactoperoxidase system. International Journal of Food Microbiology. 88: 1-9.

Wong, H.C.; Chen, M.C.; Liu, S.H. and Liu, D.P. (1999). Incidence of highly genetically diversified Vibrio parahaemolyticus in seafood imported from Asian countries. International Journal of Food Microbiology. 52: 181-188.

Younis, A.M. and Nafea, S.M. (2012). Impact of Environmental Conditions on the Biodiversity of Mediterranean Sea Lagoon, Burullus Protected Area, Egypt. World Applied Sciences Journal, 19: 1423-1430.

Younis, A.M., El-Zokm, G.M. and Okbah, M.A. (2014). Spatial Variation of AcidVolatile Sulfide and Simultaneously Extracted Metals in Egyptian Mediterranean Sea Lagoon Sediments. Environmental Monitoring and Assessment, 186: 3567-3579.

Younis, A.M., Soliman Y. A.; Elkady E. M. and El-Naggar M. H. (2018a). Assessment of polycyclic aromatic hydrocarbons in surface sediments and some fish species from the Gulf of Suez, Egypt. Egyptian Journal of Aquatic Biology \& Fisheries, 22(4): 49- 59.

Younis, A.M. (2018b). Environmental Impacts on Egyptian Delta Lakes' Biodiversity: A Case Study on Lake Burullus. A.M. Negm et al. (eds.), Egyptian Coastal Lakes and Wetlands: Part II - Climate Change and Biodiversity, Hdb Env Chem, DOI 10.1007/698_2017_120.

Youssef, H.; El-Timawy, A.K. and Ahmed, S. (1992). Role of aerobic intestinal pathogens of fresh water fish in transmission of human diseases. Journal of Food Control. 4: 34-40. 